\title{
PRAKTEK TANGGUNG JAWAB SOSIAL PERUSAHAAN DI PROVINSI RIAU: TINJAUAN ATAS HARAPAN DAN KENYATAAN
}

\author{
JULINA, SE. M.Si \\ julina22@ymail.com \\ Fakultas Ekonomi dan Ilmu Sosial UIN Suska Riau,
}

\begin{abstract}
This paper tries to find out the expectation and realities of corporate social responsibility (CSR) activities in Riau Provinsi. 172 respondents were participated in this research. Based on the data, it concluded that more than fifty percent respondents feel the CSR activities in Riau Provinsi are below their expectation. This study also explored several positive and negative impact of companies operated in Riau Province. It is important to note that $70 \%$ responden didn't have any idea for what companies who come first into mind when thinking about socially responsible companies in Riau Province. To be socially responsible, companies should pay attention in several issues like employee, goods and service, community, and charity programs.
\end{abstract}

Keyword: Corporate Social Responsibility, Expectation, Reality

PENDAHULUAN

$\begin{array}{cc}\text { Tanggung jawab } & \text { sosial } \\ \text { perusahaan } & \text { (Corporate }\end{array}$ Responsibility atau selanjutnya disingkat CSR) merupakan konsep bahwa organisasi memiliki suatu tanggung jawab terhadap semua pihak yang akan dipengaruhi oleh segala aspek operasional perusahaan. Keharusan perusahaan untuk bertanggungjawab secara sosial dimulai sejak tahun 1960an, dimana banyak perusahaan memperluas kegiatannya secara internasional dan tumbuh dengan cepat (Lantos, 2001 seperti dikutip dalam Sriramesh, Ng, Ting, and Wanyin, 2007). Permasalahan mendasar dalam bidang CSR adalah tidak adanya definisi dari konsep CSR yang diterima secara universal. Bowen (1953) menawarkan satu definisi awal menganai CSR sebagai kewajiban perusahaan untuk membuat kebijakan yang memiliki tanggung jawab, membuat keputusan yang bertanggungjawab, atau melakukan kegiatan yang selaras dengan tujuan dan nilai-nilai masyarakat. Sejak saat itu, bidang CSR ini telah berkembang dengan berbagai nama yang berbeda seperti corporate social responsiveness (pada tahun 1970an) dan corporate social performance (pada tahun 1980an). Perkembangan ini juga mencerminkan peningkatan kesadaran pada area tindakan dan kinerja yang diabaikan pada definisi awal CSR (Carroll, 1991 dalam Sriramesh, et al, 2007).

Jika ingin menggunakan definisi yang paling popular, barangkali bisa merujuk pada ISO 26000 yang menyatakan bahwa tanggung jawab sosial adalah tanggung jawab suatu organisasi atas dampak dari aktivitas dan keputusannya pada masyarakat dan lingkungan,melalui perilaku yang etis dan transparan yang memberikan kontribusi pengembangan berkelanjutan termasuk kesehatan dan kesejahteraan masyarakat; mempertimbangkan harapan pemegang 
saham; sejalan dengan hukum yang dapat diterapkan, dan konsisten dengan norma internasional tentang perilaku dan terintegrasi disepanjang organisasi dan dipraktekkan dalam hubungannya (www.csrindonesia .com)

Definisi lain menggabungkan antara etika perusahaan dengan tanggung jawab sosial ini yang disebut dengan Corporate Etchic Social Responsibility (CESR). Etika berkaitan dengan nilai yang memandu perilaku manusia. Berdasarkan prinsip-prinsip moral etika terutama berkaitan dengan penentuan prinsip yang membedakan antara benar dan salah, baik dan buruk, kebenaran dan kepalsuan. Disatu sisi, kedua konsep ini berbeda karena keduanya diaplikasikan pada dua level perusahaan yang berbeda yaitu internal dan eksternal. Disisi lain kedua konsep saling melengkapi karena CSR meliputi seluruh komponen dari etika bisnis. Etika tidak hanya sebuah komponen dari CSR, melainkan fondasinya. Pada level internal, perusahaan mengadopsi pendekatan etika yang bertujuan untuk memelihara kesatuan dan keefektivan sistem organisasi. Terdapat kebutuhan bagi perusahaan untuk menciptakan referensi budaya umum dan menjelaskan nilainilai, juga kesediaan untuk mengarahkan dan mengawasi perilaku karyawan. Norma-norma dan nilai yang ada pada umumnya secara implisit sehingga tidak cukup untuk mengarahkan karyawan untuk menghadapi masalah-masalah etika selain dari kontradiksi dan inkonsistensi yang dapat meningkatkan standar. Oleh karena itu, etika perusahaan didifusikan secara internal melalui peraturan, kode etik, dan nilai-nilai. Pada tingkat eksternal perusahaan mengadopsi CSR. Perusahaan mengimplementasikan CSR sebagai respon tekanan dan konsumen yang semakin meningkat pada aspek lingkungan dan sosial perusahaan dan pada respon tekanan persaingan. CSR adalah alat bagi perusahaan untuk membedakan mereka dari pesaing, untuk mempromosikan imej positif perusahaan melalui perumusan komitmen otonomi, meningkatkan reputasi perusahaan, dan menciptakan iklim kepercayaan antara perusahaan dan stakeholder. Tujuannya untuk mengelola keseluruhan hubungan antara perusahaan dan semua pemangku kepentingan eksternal (Amine, Chakor, Alaoui, 2013).

Saat ini, CSR mendapatkan peningkatan perhatian di seluruh dunia dan telah menjadi isu penting dalam agenda diplomasi internasional. Beberapa perjanjian antar pemerintah seperti konvensi International Labor Organization (ILO) telah dilakukan selama bertahun-tahun. Pada pertemuan World Economic Summit di Davos pada tahun 2000, sekretaris PBB Kofi Annan mengumumkan Global Compact sebagai usaha untuk membuat semua perusahaan di dunia secara sukarela melakukan CSR dalam operasi mereka. Sepuluh prinsipprinisp CSR yang meliputi empat area penting seperti hak-hak manusia, standar tenaga kerja, perlindungan lingkungan, dan anti korupsi telah ditetapkan dan perusahaan secara sukarela diminta untuk mengadopsi dan mengatur prinsip-prinsip ini dalam perusahaan (Sriramesh, et al. 2007).

Perhatian dan implementasi praktik-praktik CSR di Asia pada umumnya lebih rendah dibandingkan dengan negara-negara barat. Globalisasi muncul sebagai satu faktor terbesar yang telah mendorong berkembangnya CSR di Asia (Chambers, Chapple, Moon, \& 
Sullivan, 2003). Perusahaan yang berasal dari Asia yang ingin memperluas pasar secara internasional harus meningkatkan standar CSR mereka untuk menyesuaikan diri dengan harapan global stakeholder agar tetap dapat bersaing (Khanna, 2004b). Cara CSR dipraktekkan dan dipersepsikan dibentuk oleh budaya, agama, politik, dan kondisi sosial ekonomi. Oleh karena itu, terdapat kemungkinan adanya perbedaan yang signifikan dalam melakukan CSR antara daerah dan negara yang berbeda (Bronn \& Vrioni, 2001).

Peningkatan program CSR yang diimplementasikan perusahaan tidak secara mutlak berarti masyarakat yang tinggal disekitar perusahaan memiliki imej positif terhadap perusahaan. Terutama jika masyarakat tidak mengetahui apa yang telah dilakukan perusahaan. Kadangkala, program CSR yang dijalankan tidak sesuai dengan kebutuhan masyarakat, atau tidak dipublikasikan secara luas sehingga masyarakat tidak tahu, bisa pula disebabkan masyarakat memiliki harapan yang tinggi mengenai apa yang seharusnya dilakukan oleh perusahaan yang beroperasi di daerah mereka. Misalnya, pada bulan Agustus 2010, mahasiswa Universitas Lancang Kuning melakukan demo terhadap salah satu perusahaan besar di Propinsi Riau yaitu PT. Chevron Pacific Indonesia (CPI). Mereka menuntut perusahaan agar transparan mengenai dana bagi hasil, memperhatikan nasib ribuan tenaga buruh outsource yang terkatung-katung, dan memberikan dukungan moril dan materil pada dunia pendidikan di Riau (http://andukot.wordpress.com).

Sementara itu, disisi lain PT. CPI adalah salah satu kandidat potensial untuk menerima penghargaan dari Menkop dan UKM pada tahun 2011 untuk pelaksanaan program CSR (http://riauterkini.com). Hal ini tentu saja merupakan hal yang bertentangan antara apa yang telah dilakukan dengan apa yang dipersepsikan masyarakat. Berdasarkan fenomena yang ada perlu dilakukan penelitian untuk mengetahui bagaimana masyarakat mempersepsikan program-program CSR yang telah diimplementasikan di daerah mereka. Makalah ini mencoba untuk mengetahui persepsi masyarakat, khususnya mahasiswa UIN Suska Riau terhadap kegiatan CSR didaerah mereka (Propinsi Riau). Mahasiswa biasanya lebih kritis dalam menyikapi lingkungan mereka, dan mereka merupakan agen perubahan di masyarakat. Dengan mengetahu persepsi mereka, sikap, dan harapan, kesenjangan antara apa yang dibutuhkan masyarakat dengan apa yang harus dilakukan oleh perusahaan dapat diselaraskan. Melalui makalah ini, perusahaan juga dapat mengukur apakah cara mereka mengkomunikasikan kegiatan CSR mereka efektif atau tidak.

\section{TINJAUAN PUSTAKA}

Menurut definisi yang dapat diterima secara umum, CSR adalah ketertarikan sosial perusahaan pada pelanggannya dan sebagai suatu kemampuan untuk bertanggungjawab atas pengaruh yang ditimbulkan terhadap pelanggannya, para stake holders, pekerja, dan seluruh masyarakat. CSR tidak hanya sejenis orientasi selektif dalam dunia bisnis, tetapi tanggung jawab sosial untuk mengambil langkah yang diperlukan untuk membuat kondisi pelanggan dan karyawannya menjadi lebih baik. CSR menjamin perusahaan memperhatikan masyarakat lokal dan 
dengan kegiatannya perusahaan meningkatkan kondisi lingkungan dari variabel manusianya (www.essay911.com). Definisi lain dari CSR adalah suatu konsep bahwa organisasi, khususnya (namun bukan hanya) perusahaan adalah memiliki suatu tanggung jawab terhadap konsumen, karyawan, pemegang saham, komunitas dan lingkungan dalam segala aspek operasional perusahaan. CSR juga dikaitkan dengan komitmen perusahaan untuk meminimumkan atau mengeliminasi dampak negatif pada masyarakat dan memaksimumkan manfaatnya dalam jangka panjang (Dean, 2003).

CSR adalah suatu bentuk peraturan yang dibuat sendiri oleh perusahaan yang diintegrasikan dengan model bisnis. Kebijakan CSR berfungsi sebagai mekanisme dimana perusahaan memonitor dan menjamin aktivitasnya sesuai dengan hukum, stadar etika, dan norma internasional. Tujuan CSR adalah melakukan tanggung jawab atas tindakan perusahaan dan mendorong dampak positif melalui aktivitasnya terhadap lingkungan, konsumen, karyawan, stakeholders dan semua anggota masyarakat. Lebih jauh, perusahaan yang memfokuskan pada CSR akan secara proaktif mendorong pertumbuhan dan pengembangan masyarakat, dan secara sukarela mengeliminasi praktik-praktik yang membahayakan lingkungan.

Banyak pendukung CSR yang memisahkan CSR dari sumbangan sosial dan "perbuatan baik" (atau kedermawanan seperti misalnya yang dilakukan oleh Habitat for Humanity atau Ronald McDonald House), namun sesungguhnya sumbangan sosial merupakan bagian kecil saja dari CSR.
Perusahaan di masa lampau seringkali mengeluarkan uang untuk proyek-proyek komunitas, pemberian beasiswa dan pendirian yayasan sosial. Mereka juga seringkali menganjurkan dan mendorong para pekerjanya untuk sukarelawan (volunteer) dalam mengambil bagian pada proyek komunitas sehingga menciptakan suatu itikad baik dimata komunitas tersebut yang secara langsung akan meningkatkan reputasi perusahaan serta memperkuat merek perusahaan. Dengan diterimanya konsep CSR, terutama triple bottom line, perusahaan mendapatkan kerangka baru dalam menempatkan berbagai kegiatan sosial di atas.

Untuk menunjukkan bahwa perusahaan adalah warga dunia bisnis yang baik maka perusahaan dapat membuat pelaporan atas dilaksanakannya beberapa standar CSR termasuk dalam hal:

1. Akuntabilitas atas standar AA1000 berdasarkan laporan sesuai standar John Elkington yaitu laporan yang menggunakan dasar triple bottom line (3BL)

2. Global Reporting Initiative, yang mungkin merupakan acuan laporan berkelanjutan yang paling banyak digunakan sebagai standar saat ini.

3. Verite, acuan pemantauan

4. Laporan berdasarkan standar akuntabilitas sosial internasional SA8000

5. Standar manajemen lingkungan berdasarkan ISO 14000

Istilah CSR menjadi umum digunakan pada akhir tahun 1960an dan awal 1970an, setelah banyak perusahaan multinasional didirikan. Istilah stakeholder, yang berarti pihak-pihak yang dipengaruhi oleh perusahaan, 
digunakan untuk menggambarkan pemilik perusahaan diatas pemegang saham sebagai hasil dari buku yang ditulis oleh R. Edward Freeman, Strategic management: a stakeholder approach in 1984. Para pendukung CSR menyatakan bahwa perusahaan menghasilkan keuntungan jangka panjang dengan melakukan aktivitas yang memiliki perspektif tertentu, sementara para kritikus CSR menyatakan bahwa CSR berbeda dari peran ekonomis suatu bisnis. Pihak-pihak lain menyatakan CSR semata-mata semacam polesan agar perusahaan terlihat bagus, atau suatu usaha untuk mencegah peran pemerintah sebagai pengawas atas kekuatan perusahaan multinasional (www.wikipedia.com).

Globalisasi telah memainkan peran penting dalam menjadi katalisator bagi CSR. Tidak mengherankan bahwa perusahaan multinasional adalah pendukung utama CSR. Banyak perusahaan multinasional memiliki kantor pusat di negara barat dengan demokrasi liberal dimana organisasi ditekan oleh peraturan pemerintah, media massa, lembaga swadaya masyarakat, untuk bertanggungjawab secara sosial. Perusahaan multinasional memiliki cabang di seluruh dunia, dengan rantai pasokan dan pabrik pembuatan yang berlokasi di berbagai negara. Selain itu, operasi bisnis telah menjadi lebih transparan dengan adanya peningkatan teknologi informasi dan komunikasi modern. Hal ini menjamin tindakan perusahaan yang tidak bertanggungjawab atau tidak etis akan diawasi publik dan para kritikus (Sriramesh, et.all. 2007).

Sebuah penelitian yang menggunakan instrumen kuesioner tertutup yang terperinci dilakukan pada pimpinan tertinggi perusahaan menemukan bahwa tidak terdapat hubungan antara kegiatan CSR dengan profitabilitas perusahaan. Khususnya, berbagai tingkat orientasi sosial tidak berkorelasi dengan kinerja perusahaan (Auppele, Carroll, \& Hatfield, 1985). Penelitian lain yang dilakukan oleh Hochgatterer menemukan hubungan positif antara CSR dan keuntungan perusahaan dan menemukan bahwa perusahaan-perusahaan yang menjalankan aktivitas CSR lebih stabil. Kedua penelitian ini menemukan hasil yang berlawanan. Bagaimanapun, sejak CSR menjadi trend bisnis yang semakin meningkat, bersedia atau tidak, perusahaan harus mulai memikirkan perencanaan strategis mereka yang melibatkan program-program.

Keragaman kepulauan di Indonesia memiliki kemiripan dengan Amazon Basin (Barber, 1998). Dan sebagaimana Amazon Basin, biodiversitas dan keseimbangan ekologis Indonesia terancam dengan adanya penambangan besar-besaran, peralihan sawah menjadi kelapa sawit, dan aktivitas penebangan hutan. Dibawah undang-undang Indonesia, setiap tanah yang tidak digunakan untuk pertanian, perumahan, atau industri, secara otomatis dimiliki oleh pemerintah, dan mengabaikan klaim tradisional atas tanah-tanah adat. Ini berarti sumber daya alam dapat dieksploitasi tanpa bagi hasil pada masyarakat lokal. Indonesia adalah produsen utama tin, batubara dan tembaga. Tanah Indonesia memiliki cadangan pasir besi yang sangat banyak, bauksit, dan fosfat. Pendapatan utamanya dari emas, dan terlihat bahwa berliannya akan menjadi bisnis yang menguntungkan. Hutannya penuh dangan 
pohon-pohon keras dan pohon jati yang dapat diolah menjadi lemari atau perabotan lain. Meskipun hal ini sebenarnya adalah berita baik bagi kondisi perekonomian yang miskin, namun dengan tidak adanya etika bisnis dan program sosial dan adanya kapitalisme dan kroni, kegiatan yang merusak lingkungan akan terjadi (Kemp, 2001). Berdasarkan hasil penelitian yang dilakukan oleh Kemp, dapat dipahami mengapa kadangkala masyarakat atau mahasiswa melakukan demo terhadap perusahaan yang telah mengeksplorasi sebanyak mungkin sumber daya alam tanpa memberikan manfaat kepada masyarakat di sekitarnya. Hal ini juga menjadi alasan mengapa pengimplementasian CSR di Indonesia harus dilakukan sesegera mungkin dan pemerintah harus berperan aktif mengawasinya.

Terdapat empat model implementasi CSR di Indonesia:

1. Terlibat langsung. Perusahaan melakukan program CSR tanpa perantara.

2. Melalui organisasi sosial perusahaan. Model ini diadopsi dari implementasi CSR di negara maju.

3. Bekerjasama dengan pihak lain seperti LSM, universitas, atau media massa dalam mengelola dana dan mengimplementasikan aktivitas sosial.

4. Mendukung atau bergabung dengan konsorsium untuk melakukan porgram-program CSR. (Saidi 2004 seperti dikutip dalam Tanudjaja, 2006)

Kotler dan Lee menyebutkan bahwa setidaknya ada 6 opsi untuk "berbuat kebaikan" (Six options for Doing Good) sebagai inisiatif sosial perusahaan yang dapat ditempuh dalam rangka implementasi CSR, yaitu (Kotler dan Lee,
2003 seperti dikutip dalam Nasution, 2008):

1. Cause Promotions. Suatu perusahaan dapat memberikan dana atau berbagai macam kontribusi lainnya, ataupun sumber daya perusahaan lainnya untuk meningkatkan kesadaran masyarakat atas suatu isu sosial tertentu, ataupun dengan cara mendukung pengumpulan dana, partisipasi dan rekruitmen sukarelawan untuk aksi sosial tertentu. Contohnya perusahaan kosmetika terkemuka di Inggirs, The Body Shop, mempromosikan larangan untuk melakukan uji produk terhadap hewan.

2. Cause-Related Marketing. Suatu perusahaan dalam hal ini berkomitmen untuk berkontribusi atau menyumbang sekian persen dari pendapatannya dari penjualan suatu produk tertentu miliknya untuk isu sosial tertentu. Contohnya seperti Unilever yang memberikan sekian persen dari penjualan sabun produksinya, Lifebuoy, untuk meningkatkan kesadaran hidup bersih dalam masyarakat, dengan cara membangun fasilitas kamar kecil dan wastafel di sekolah-sekolah, terutama di daerahdaerah terpencil.

3. Corporate Social Marketing. Suatu perusahaan dapat mendukung perkembangan atau pengimplementasian kampanye untuk merubah cara pandang maupaun tindakan, guna meningkatkan kesehatan publik, keamanan, lingkungan, maupun kesejahteraan masyarakat. Contohnya seperti Unilever yang memrpoduksi pasta gigi Pepsodent mendukung kampanye gigi sehat.

4. Corporate Philanthropy. Dalam hal ini, suatu perusahaan secara langsung dapat memberikan sumbangan, 
biasanya dalam bentuk uang tunai. Pendekatan ini merupakan bentuk implementasi tanggung jawab sosial yang paling tradisional. Contohnya suatu perusahaan dapat langsung memberikan bantuan uang tunai ke panti-panti sosial, ataupun apabila tidak uang tunai, dapat berupa makanan ataupun alat-alat yang diperlukan.

5. Community Volunteering. Dalam hal ini, perusahaan dapat mendukung dan mendorong pegawainya, mitra bisnis maupun para mitra waralabanya untuk menjadi sukarelawan di organisasiorganisasi kemasyarakatan lokal. Contohnya suatu perusahaan dapat mendorong atau bahkan mewajibkan para pegawainya untuk terlibat dalam bakti sosial atau gotong-royong di daerah dimana perusahaan itu berkantor.

6. Socially Responsible Business Practices. Misalnya perusahaan dapat mengadopsi dan melakukan praktekpraktek bisnis dan investasi yang dapat mendukung isu-isu sosial guna meningkatkan kelayakan masyarakat (community well-being) dan juga melindungi lingkungan. Seperti contohnya Starbucks bekerjasama dengan Conservation International di Amerika Serikat untuk mendukung petani-petani guna meminimalisir dampak atas lingkungan mereka.

\section{Strategi Perusahaan dalam Mengelola CSR}

Ada beberapa strategi yang dapat dilakukan oleh perusahaan (Sule dan Saefullah, 2005):

1. Strategi Reaktif: kegiatan bisnis yang melakukan strategi reaktif dalam tanggung jawab sosial cenderung menolak atau menghindarkan diri dari tanggung jawab sosial.contoh: perusahaan tembakau cenderung menghindarkand iri dari isu yang menghubungkan antara konsumsi rokok dengan peluang penyakit kanker.

2. Strategi Defensif: strategi defensif yang dilakukan perusahaan terkait dengan penggunaan pendekatan legal atau jalur hukum untuk menghindarkan diri atau menolak tanggung jawab sosial. Perusahaan yang menghindari tanggung jawab penanganan limbah bisa berargumen melalui pengacara bahwa tidak hanya perusahaannya yang membuang limbah.

3. Strategi Akomodatif: beberapa perusahaan memberikan tanggung jawab sosial berupa pelayanan kesehatan, kebersihan, dll bukan karena perusahaan menyadari perlunya tanggung jawab sosial, namun dikarenakan adanya tuntutan dari masyarakat dan lingkungan akan hal tersebut. Contohnyha perusahaan besar yang memberikan pinjaman lunak karena ada tuntutan dari pemerintah.

4. Strategi Proaktif: kegiatan bisnis yang melakukan strategi proaktif dalam tanggung jawab sosial memandang bahwa tanggung jawab sosial adalah bagian dari tanggung jawab untuk memuaskan stakeholders. Dalam jangka panjang perusahaan berpotensi menambah jumlah pelanggan karena citra positif yang disandangnya.

\section{Faktor Penentu Implementasi CSR}

Terdapat berbagai faktor yang mempengaruhi suatu perusahaan dalam mengimplemetasikan program CSR. Secara umum faktor tersebut dapat dibagi 
menjadi faktor internal dan eksternal. Dari sis eksternal, pemerintah sebagai pihak yang berkuasa pada suatu daerah dapat menerapkan peraturan yang mewajibkan perusahaan melaksanakan program CSR. Begitu pula, masyarakat disekitar, konsumen yang menggunakan produk dan jasa yang dihasilkan perusahaan, lembaga swadaya yang juga terkadang menjadi pemantau pelaksanaan CSR, dan juga tuntutan dari negaranegara lain yang dapat mempengaruhi keberlanjutan perusahaan. Dari sisi internal, orientasi perusahaan juga akan dapat menentukan apakah perusahaan akan melaksanakan tanggung jawab sosial ini atau tidak. Bagian selanjutnya akan membahas berbagai hal yang mempengaruhi perusahaan melakukan praktek CSR baik dari sisi teori maupun riset empiris yang pernah dilakukan.

Hasil penelitian yang dituangkan dalam gambar 1 menunjukkan bahwa tanggungjawab merupakan hal yang paling penting menurut penelitian dari 23 negara di dunia dengan jumlah sampel sekitar 25.000 orang dewasa (Dawkins dan Lewis, 2003). Terlihat bahwa tanggung jawab merupakan hal yang paling penting yang dapat mempengaruhi reputasi perusahaan.

Gambar 1

Faktor Penting dalam Reputasi Perusahaan

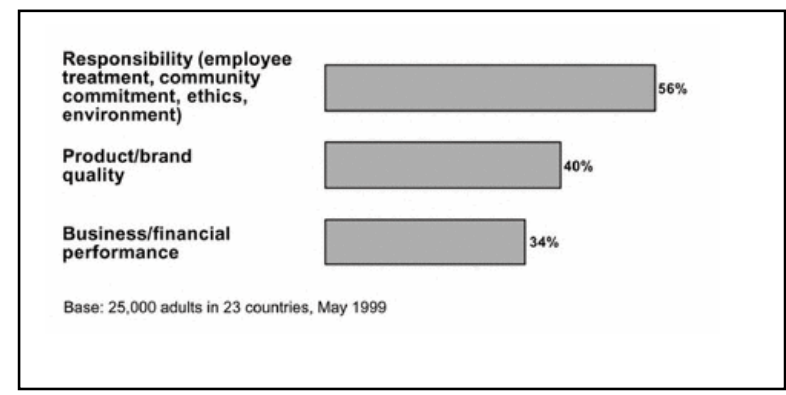

\section{Suatu Kewajiban}

Pada awalnya, perusahaan menganggap tanggung jawab mereka hanyalah sebatas memberikan keuntungan maksimum bagi para pemegang saham. Namun selanjutnya tanggung jawab ini berkembang menjadi lebih besar dan telah menjadi kebijakan publik secara nasional yang diatur dalam undangundang resmi bahwa perusahaan harus bertanggung jawab kepada lingkungan, karyawan, dan konsumen (Dean, 2003).

Menurut Peraturan Pemerintah Republik Indonesia Nomor 47 Tahun
2012 tentang Tanggung Jawab Sosial dan Lingkungan Perseroan Terbatas dinyatakan setiap perseroan selaku subjek hukum mempunyai tanggung jawab sosial dan lingkungan yang menjadi kewajiban bagi perseroan yang menjalankan kegiatan usahanya dibidang dan/atau berkaitan dengan sumber daya alam. Kewajiban ini harus dilaksanakan baik didalam maupun diluar lingkungan perseroan. Selanjutnya Pasal 7 menegaskan bagi perusahaan yang tidak melaksanakan tanggung jawab sosial dan lingkungan dikenai sanksi sesuai dengan ketentuan peraturan perundang-undangan. 


\section{Suatu Investasi}

CSR telah berkembang dari tahap awal yang merupakan tindakan sukarela suatu perusahaan menjadi tanggung jawab yang diatur oleh undang-undang, dan sekarang masanya dimana tanggung jawab sosial dipandang perusahaan sebagai investasi yang meningkatkan kinerja organisasi dalam jangka panjang. Kegiatan CSR ini dapat menghasilkan berbagai manfaat seperti (Dean, 2003):

1. Menciptakan kebaikan atau perhatian kepada masyarakat.

2. Pembedaan image dan merek perusahaan dari pesaing.

3. Penerimaan yang lebih besar oleh konsumen terhadap kenaikan harga.

4. Perekrutan tenaga kerja baru.

5. Menjadi tameng atas kritik masyarakat pada masa krisis.

6. Sebagai bantuan dalam melakukan lobby ke pemerintah

7. Meningkatkan pendapatan dan keuntungan.

Hasil penelitian Raman, Lim, dan Nair (2012) menemukan bahwa semakin tinggi praktek CSR semakin kuat loyalitas pelanggan dari suatu perusahaan. Penelitian ini juga menemukan bahwa dengan berinvestasi dalam CSR suatu perusahaan dapat mencapai hasil positif pada kinerja finansialnya. CSR dapat menyediakan keunggulan kompetitif tambahan bagi perusahaan tertentu.

\section{Gaya Kepemimpinan}

Gaya kepemimpinan tidak diragukan lagu dapat mempengaruhi banyak hal. Banyak penelitian yang telah menganalisis pengaruh gaya kepemimpinan terhadap kepuasan kerja karyawan dan bahkan kesuksesan organsasi melalui strategi-strategi yang disusunnya. Du, Swaen, Lindgreen dan Sen (2013) tertarik untuk meneliti pengaruh gaya kepemimpinan terhadap implementasi CSR. Khususnya gaya kepemimpinan transformasional dan transaksional. Penelitian mereka meneliti interaksi antara gaya kepemimpinan dan praktek tanggung jawab sosial perusahaan (CSR) perusahaan. Sebuah survei lapangan skala besar pada para manajer mengungkapkan bahwa perusahaan dengan gaya kepemimpinan transformasi yang lebih besar lebih mungkin untuk terlibat dalam praktek CSR perusahan, sedangkan kepemimpinan transaksional tidak terkait dengan praktek-praktek tersebut. Selain itu, stakeholders yang berorientasi pemasaran memperkuat hubungan positif antara kepemimpinan transformasional dan praktik CSR perusahan. Akhirnya, kepemimpinan transaksional meningkatkan, sedangkan kepemimpinan transformasional menurunkan, hubungan positif antara praktik CSR perusahaan dan hasil organisasi. Penelitian ini menyoroti perbedaan peran yang dimainkan oleh gaya kepemimpinan transformasional dan transaksional untuk praktik CSR perusahaan dan memiliki implikasi yang signifikan untuk teori dan praktek.

Kepemiminan merupakan proses dimana seorang individu mempengaruhi sekelompok individu untuk mencapai suatu tujuan. Secara sederhana kepemimpinan transformasional dapat diartikan sebagai proses untuk merubah dan mentransformasikan individu agar mau berubah dan meningkatkan dirinya, yang didalamnya melibatkan motif dan 
pemenuhan kebutuhan serta penghargaan terhadap para bawahan. Terdapat empat faktor untuk menuju kepemimpinan tranformasional, yang dikenal sebutan 4 I, yaitu : idealized influence, inspirational motivation, intellectual stimulation, dan individual consideration. Idealized influence: pimpinan merupakan sosok ideal yang dapat dijadikan sebagai panutan bagi para bawahannya, dipercaya, dihormati dan mampu mengambil keputusan yang terbaik untuk kepentingan perusajaan. Inspirational motivation: pimpinan dapat memotivasi seluruh karyawannnya untuk memiliki komitmen terhadap visi organisasi dan mendukung semangat team dalam mencapai organisasi. Intellectual Stimulation: pimpinan dapat menumbuhkan kreativitas dan inovasi di kalangan karyawannya dengan mengembangkan pemikiran kritis dan pemecahan masalah untuk menjadikan perusahaan ke arah yang lebih baik. Individual consideration: pimpinan dapat bertindak sebagai pelatih dan penasihat bagi karyawannya. Berdasarkan hasil kajian literatur yang dilakukan, Northouse (2001) menyimpulkan bahwa seseorang yang dapat menampilkan kepemimpinan transformasional ternyata dapat lebih menunjukkan sebagai seorang pemimpin yang efektif dengan hasil kerja yang lebih baik. Oleh karena itu, merupakan hal yang amat menguntungkan jika para pemimpin dapat menerapkan kepemimpinan transformasional di perusahannya. Karena kepemimpinan transformasional merupakan sebuah rentang yang luas tentang aspek-aspek kepemimpinan, maka untuk bisa menjadi seorang pemimpin transformasional yang efektif membutuhkan suatu proses dan memerlukan usaha sadar dan sungguhsungguh dari yang bersangkutan. (http://id.wikipedia.org/wiki/Kepemimpin an)

\section{Kinerja Keuangan}

Banyak peneliti yang telah melakukan penelitian dampak dari program CSR terhadap kinerja keuangan perusahaan. Hasilnya sangat beragarm. Ada yang menemukan hubungan positif, negatif, atau netral. Ketidak konsistenan ini barangkali disebabkan oleh kesalahan dalam pengujian empiris. McWilliams dan Siegel (2000) dalam penelitiannya mencoba menganalisis kesalahan tertentu yang ada dalam studi ekonometrik atas hubungan antara kinerja keuangan dan sosial. Penelitian mereka mencoba mengestimasi pengaruh CSR dengan melakukan regresi CSR dan kinerja keuangan dengan beberapa variabel kontrol. Mereka menemukan salah satu kesalahan dalam mengalisis hubungan ini adalah tidak memperhitungkan investasi dalam penelitian dan pengembangan yang merupakan faktor penting dalam kinerja perusahaan. Kesalahan ini menimbulkan bias dan ketika model ditetapkan dengan tepat, mereka menemukan dampak yang netral antara pengimplementasian CSR dengan kinerja keuangan.

Kinerja keuangan yang menurun, biasanya akan menyebabkan penurunan juga kegiatan CSR. Hal ini terungkap dari penelitian yang dilakukan oleh Giannarakis dan Sariannidis (2012). Mereka mencoba kegiatan CSR pada masa lingkungan bisnis tidak stabil. Indeks CSR yang disusun oleh Boston College Center and Reputation Institute digunakan untuk mengukur kegiatan CSR di Amerika pada periode tahun 2008, 
2009 dan 2010. Periode 2008-2010 dicirikan oleh peningkatan ketidakstabilan ekonomi golbal dan dipertimbangkan sebagai kondisi ekonomi terburuk setelah perang dunia kedua. Hasil pengujian dengan uji Wilcoxon menunjukkan indeks tanggung jawab sosial perusahan menurun selama periode 2008-2009 sementara kinerja CSR meningkat pada periode 2009-2010 untuk memperkuat reputasi mereka agar mendapatkan kembali izin beroperasi.

\section{CSR dimasa Mendatang}

Pengimplementasian CSR memang tidak selalu berjalan sesuai dengan apa yang seharusnya dilakukan. Berbagai pihak saling memperdebatkan pro dan kontra dalam pengimplementasian CSR ini. Berikut dikemukakan pandangan dari kelompok yang pro terhadap pengimplementasian CSR (Sule dan Saefullah, 2005):

1. Kegiatan bisnis seringkali menimbulkan masalah, oleh karena itu sudah semestinya perusahaan ber tanggung jawab atas apa yang dilakukannya.

2. Perusahaan adalah bagian dari lingkungan sosial masyarakat, oleh karena itu sudah semestinya ikut berpartisipasi dan ber tanggung jawab atas apa yang terjadi di masyarakat.

3. Perusahaan biasanya memiliki sumber daya untuk menyelesaikan masalah di lingkungan sosial masyarakat

4. Perusahaan adalah partner dari lingkungan sosial kemasyarakatan, sebagai mana halnya juga pemerintah dan masyarakat lain pada umumnya

Selanjutnya, bagi pihak yang kontra, argumen yang mereka kemukakan adalah sebagai berikut:
1. Perusahaan tidak memiliki ahli yang mengkhususkan dalam bidang sosial kemasyarakatan, oleh karena itu sulit bagi perusahaan bertanggung jawab

2. Perusahaan yang ikut berpartisipasi dan bertanggungjawab dalam lingkungan sosial masyarakat justru akan memiliki kekuatan untuk mengontrol masyarakat dan itu indikasi yang kurang baik secara sosial.

3. Akan banyak terdapat konflik kepentingan di masyarakat jika perusahaan terlibat dalam aktivitas sosial.

4. Tujuan perusahaan bukan untuk motif sosial, akan tetapi untuk memperoleh profit dan mencapai tujuan yang diharapkan oleh para pemilik perusahaan.

Trend untuk mengimplementasikan CSR dalam bisnis semakin meningkat. Menurut riset yang dilakukan oleh Cone sebanyak enam dari sepuluh konsumen berkata saat ini mereka lebih menyukai membeli produk ramah lingkungan dibandingkan tahun-tahun sebelumnya. Sebuah survey yang dilakukan oleh Deloitte menemukan bahwa 18 persen pembeli akan membeli produk yang "eco-friendly" pada musim liburan kali ini dibandingkan tahun lalu, dan sejumlah yang sama akan berbelanja pada toko atau retailer yang lebih ramah lingkungan. Menurut artike ini, toko Target tidak mengirimkan pesan ramah lingkungan dalam pemasaran untuk liburan kali ini. Wal-Mart juga menyatakan mereka tidak memiliki perencanaan pemasaran yang ramah lingkungan pada liburan natal. Dan juru bicara J.C. Penney menyatakan terlalu dini untuk membuat perubahan besar dalam menjual dan mempromosikan 
barang-barang yang ramah lingkungan. Satu retailer yang membuat musim liburan ramah lingkungan hanyalah Barneys. (Anonym, 2007)

Lebih jauh, terdapat kenyataan fantastis pada gerakan konsumen ramah lingkungan (Ribeiro, 2010):

1. 2 dari 4 orang America setuju bahwa planet yang lebih bersih bermula dari rumah.

2. 2 dari 3 siap melakukan perubahan.

3. $84 \%$ responden menyatakan mereka mendasarkan pilihannya pada isu-isu lingkungan.

4. $87 \%$ warga Amerika menyatakan bahwa pemanasan global bukan poin utama - tetapi yang lebih penting adalah pengurangan sampah.

Survey selanjutnya adalah The Millenium Poll on CSR survey (1999) yang dilakukan Environics International (Toronto), Conference Board (New York) dan Prince of Wales Business Leader Forum (London). Hasil survey menyatakan bahwa dari 25.000 responden yang berasal 23 negara, 60\% imej mereka terhadap perusahaan adalah berdasarkan etika bisnis, bagaimana mereka memperlakukan karyawan, dampak terhadap lingkungan adalah bagian dari CSR. Sementara itu $40 \%$ dari mereka menyatakan imej merek dan perusahaan alah faktor yang paling mempengaruhi kesan mereka. Hanya $1 / 3$ responden yang memberikan opini kesan mereka adalah berdasarkan faktor-faktor fundamental dalam bisnis seperti keuangan, ukuran perusahaan, strategi perusahaan atau manajemen perusahaan. Selanjutnya, sikap konsumen terhadap perusahaan yang tidak mengimplementasikan CSR adalah mereka ingin memberikan hukuman (40\%) dand 50\% tidak akan membeli produk apapun dari perusahaan tersebut dan akan berbicara hal-hal buruk tentang perusahaan kepada orang lain. Untuk menyelesaikan maslah ini, Ribeiro (2010) menyarankan beberapa hal:

1. Kaitkan kegiatan perusahaan dengan isu-isu yang mudah dihubungkan dengan konsumen seperti kesehatan mereka atau keselamatan anak-anak mereka.

2. Berhati-hati terhadap pemasaran missionary: konsumen bukanlah penyelamat planet bumi dan pesanpesarn pemasaran missionary tidak akan bertahanlama dalam mendorong kesadaran akan merek dan penjualan.

3. Pertahankan perhatian positif: produk ramah lingkungan harus baik, setidaknya membuat masyarakat merasa aman ketika membeli, mengkonsumsi, atau menggunakannya.

4. Bantu menjelaskan: konsumen ingin mengadopsi perilaku yang ramah lingkungan, tetapi banyak yang tidak tahu bagaimana. Klarifikasikan dalam bahan-bahan pemasaran dengan tepat bagaimana produk yang dibuat dapat membanti lingkungan dan masyarakat.

5. Jaga kebersihan: konsumen ingin mengkonsumi produk yang bersih dan akan membeli produk yang tidak mengandung zat kimia beracun.

6. Buat perbedaan yang dapat dilihat: orang ingin dipersepsikan ramah lingkungan juga. Semakin anda bertanggungjawab terhadap lingkungan, dan semakin anda memiiliki dampak dalam indunstri yang ramah lingkungan, semakin banyak konsumen yang akan membeli produk dan jasa anda.

7. Bawa lebih dekat ke rumah: akhirakhir ini konsumen lebih perhatian 
pada isu-isu yang terkait langsung pada kehidupan mereka, seperti kesehatan anak, kualitas udara di kantor. Kaitkan dengan sesuatu yang mereka terkait secara personal, dan kesadaran akan merek anda akan meningkat.

Wanita dan khususnya ibu-ibu sangat memperhatikan dampak dari barang dan jasa dalam kehidupan mereka, dan kemudian bagaimana barang dan jasa ini juga akan berdampak pada kesehatan keluarga mereka. Ibu adalah pembeli utama, yang memiliki pengaruh kuat atas merek apa yang dibeli.

Suatu laporan penelitian menunjukkan bahwa Ibu yang berwawasan lingkungan (EcoMoms) lebih terlibat dibandingkan konsumen lainnya, misalnya dalam hal penghematan air (matikan air ketika menggosok gigi atau aktivitas lainnya) dan penghematan energi (matikan lampu ketika meninggalkan ruangan). $35 \%$ dari EcoMoms mengirimkan anak-anak mereka ke sekolah yang tidak menimbulkan sampah dari makan siang dan snack. Berdasarkan perilakunya yang ramah lingkungan, ibu-ibu menemukan manfaat kesehatan dan kualitas kehidupan yang tidak diduga:

1. 2 dari 5 ibu-ibu menjadi lebih aktif secara fisik sebagai hasil dari gaya hidup yang lebih ramah lingkungan, dan

2. 3 dari 5 ibu-ibu mengharapkan lingkungan yang lebih bersih berarti semakin sedikit ganggunan dan kanker dimasa yang akan datang.

\section{METODOLOGI}

Penelitian ini menggunakan metode survey dengan menyebarkan kuesioner kepada mahasiswa UIN Suska Riau. Kuesioner terdiri dari pertanyaan tertutup dan terbuka. Pada pertanyaan tertutup, mahasiswa hanya memilih berdasarkan alternatif yang telah tersedia, sementara pada pertanyaan terbuka, mahasiswa bebas menjawab menurut pemahaman mereka. 172 mahasiswa dari Jurusan Manajemen dan Akuntansi berpartisipasi dalam penelitian ini. Teknik pengambilan samplenya adalah accidental sampling. Sebelum mereka mengisi kuesioner, definisi dan contoh-contoh CSR diberikan untuk memastikan mereka memahami apa topik dan tujuan penelitian ini. Data yang terkumpul selanjutnya di analisis secara deskriptif.

\section{HASIL TEMUAN DAN ANALISIS}

Bagian berikutya akan membahas mengenai hasil temuan dan analisis. Diawali dengan membahas identitas responden, harapan, kenyataan, dan dampak dari keberadaan perusahaan baik dari sisi positif maupun negatifnya.

\section{Identitas Responden}

Karakteristik responden yang menjadi sampel penelitian ini meliputi jenis kelamin, umur, dan daerah asal. Sebagian besar responden $(59 \%)$ adalah wanita, sementara $41 \%$ nya adalah pria. Mayoritas responden berusia 19 tahun (53\%), 18 tahun (28\%), 20 tahun (15\%) dan 21 tahun dan 22 tahun, masingmasing $2 \%$. Persentase terbesar mahasiswa berasal dari Kabupaten Kampar (20\%) diikuti oleh mahasiswa yang berasal dari Kabupaten Kuantan Singingi (10\%) dan Pekanbaru 13\%. Selengkapnya ditampilkan pada Tabel 1 sebagai berikut: 
Tabel 1

Karakteristik Responden

\begin{tabular}{lcc}
\hline Karakteristik & Frekuensi & Persentase \\
\hline Jenis Kelamin & & \\
\hline Pria & 71 & 41 \\
Wanita & 101 & 59 \\
Umur & & \\
\hline 18 & 48 & 28 \\
19 & 92 & 53 \\
20 & 25 & 15 \\
21 & 4 & 2 \\
22 & 3 & 2 \\
& & \\
Daerah Asal & & 8 \\
Bengkalis & 13 & 4 \\
Dumai & 7 & 3 \\
Indragiri Hilir & 5 & 5 \\
Indragiri Hulu & 8 & 20 \\
Kampar & 34 & 10 \\
Kuansing & 18 & 3 \\
Meranti & 5 & 13 \\
Pekanbaru & 22 & 7 \\
Rokan Hilir & 12 & 7 \\
Rokan Hulu & 12 & 5 \\
Siak & 8 & \\
\hline
\end{tabular}

\section{Harapan Responden}

Setiap orang memiliki harapan terhadap perusahaan yang beroperasi di daerahnya. Hal ini juga berlaku di bidang CSR yang harus dilakukan oleh perusahaan sebagai imbalan atas keuntungan yang mereka dapat dari aktivitas bisnisnya. Terkadang harapan masyarakat berbeda dengan harapan perusahaan. Hal ini membuat masyarakat merasa tidak mendapat manfaat dari perusahaan sementara perusahaan merasa telah banyak melakukan kegiatan sosial bagi masyarakat.

Menurut penelitian Majumdar dan Saini (2013), CSR dapat dipersepsikan berbeda berdasarkan umur, tingkat pendidikan, daerah asal, dan sebagainya. Orang-orang yang lebih muda berpikir dengan cara yang berbeda dan mengharapkan dampak CSR dalam jangka panjang. Pendidikan mampu mengubah pola pikir masyarakat sehingga menjadi lebih kritis dalam menghadapi aktivitas CSR perusahaan. Mereka juga memberikan perhatian terhadap kelestarian budaya daerah, nilainilai sosial, dan sumber daya alam. Disisi lain, masyarakata dengan tingkat pendidikan yang lebih rendah memberikan perhatian pada manfaat langsung dari kegiatan CSR. Persepsi juga berbeda bergantung dari daerah asal 
penduduk. Biasanya, penduduk lokal dimana organisasi beroperasi ingin mempertahankan budaya, norma, dan nilai masyarakat dan mengharapkan program CSR berkaitan dengan aktivitas seperti kelestarian budaya tradisional, bahasa, atau kerajinan tangan. Sementara para pendatang biasanya mengharapkan program CSR untuk meningkatkan kualitas kehidupan seperti pengembangan infrastruktur.

Dalam penelitian ini, dicoba untuk mengetahui apa saja harapan masyarakat atas berbagai perusahaan yang ada disekitarnya. Tabel 2 mencoba menjelaskan beberapa harapan masyarakat terhadap perusahaan.

Tabel 2

Harapan Masyarakat terhadap Perusahaan

\begin{tabular}{llc}
\hline No & Harapan & Persentase \\
\hline 1 & Meningkatkan kesejahteraan sosial & $66 \%$ \\
2 & Lowongan kerja bagi penduduk lokal & $76 \%$ \\
3 & Meningkatkan fasilitas publik dan pendidikan & $48 \%$ \\
4 & Beroperasi dengan ramah lingkungan & $35 \%$ \\
5 & Tidak tahu & $2 \%$ \\
\hline
\end{tabular}

Tabel 2 menunjukkan bahwa 66\% responden berharap perusahaan meningkatkan kesejahteraan sosial, sementara $76 \%$ mengharapkan lowongan kerja. Selanjutnya $48 \%$ responden berharap peningkatan fasilitas publik dan pendidikan dan $35 \%$ responden berharap perusahaan beroperasi dengan ramah lingkungan. Sekitar 2\% responden menjawab tidak tahu untuk menjawab pertanyaan apa yang mereka harapkan dari beroperasinya perusahaanperusahaan di Propinsi Riau. Berdasarkan data tersebut diketahui bahwa persentase terbesar harapan responden adalah mendapatkan lowongan pekerjaan. Jawaban ini juga disisi lain mengindikasikan masih rendahnya jiwa kewirausahaan pada diri responden sehingga sangat mengharapkan untuk menjadi karyawan atau pekerja dari perusahaan-perusahaan yang beroperasi di Propinsi Riau. Dari sudut pandang yang lebih luas, negara-negara maju biasanya ditopang oleh banyaknya penduduk yang menjalankan bisnis sendiri, sementara di Indonesia, persentase penduduk yang menjadi wirausahawan belum mencapai satu persen. Pertanyaan berikutnya apakah perusahaan sudah memenuhi harapan tersebut digambarkan pada Tabel 3 . Berdasarkan Tabel 3 dapat disimpulkan kenyataan bahwa lebih dari 50\% responden merasa perusahaan belum memenuhi harapan mereka dalam mengimplementasikan program CSR di Propinsi Riau. Senada dengan persepsi responden, kepala penyuluhan dan promosi koperasi dan UKM menyatakan tidak terdapat data dana CSR dari 14 perusahaan publik yang dimiliki pemerintah. Dia secara serius meminta perusahaan untuk memberikan dana CSR sesegera mungkin (Riau Terkini, 2010). Penelitian yang dilakukan oleh CSR Asia menemukan bahwa terdapat tantangan yang dihadapi perusahaan untuk 
mengimplementasikan CSR. Tantangan terberatnya adalah kurangnya dana. Selanjunya, perusahaan juga menghadapi tantangan seperti kelompok yang sedikit, ruang lingkup tanggung jawab yang besar, kurangnya pengetahuan, tidak ada dukungan pimpinan, tidak ada dukungan dari karyawan, dan sebagainya.

Tabel 3

Persepsi Responden Apakah Perusahaan sudah Memenuhi Harapan

\begin{tabular}{llc}
\hline No & Persepsi Responden & Persentase \\
\hline 1 & Sudah & $24 \%$ \\
2 & Belum & $55 \%$ \\
3 & Sebagian & $21 \%$ \\
\hline
\end{tabular}

\section{Dampak Perusahaan di Provinsi Riau}

Sekitar $43 \%$ responden menyatakan terdapat dampak positif berdirinya perusahaan di Riau adalah kesempatan kerja yang tinggi dengan adanya perusahaan tersebut. 23\% menyatakan daerah mereka semakin berkembang dengan adanya perusahaan. Sekarang, daerah mereka tidak lagi terisolir, banyak orang datang untuk mencari pekerjaan, dan kondisi ekonomi meningkat. Selanjutnya $12 \%$ responden menyatakan perusahaan memberikan bantuan kepada masyarakat. Bantuan tersebut berupa dana bantuan sosial, pembangunan sarana olah raga, pendidikan, mesjid, jalan, sekolah, sembako, panti asuhan, rumah sakit, taman bermain, fasilitas umum, dan sebagainya. Sekitar 9\% menyatakan dampak lain seperti perusahaan menyediakan kebutuhan mereka sehingga mereka tidak menghadapi kesulitan untuk memenuhi kebutuhan mereka, untuk mendapatkan barang dan jasa, mereka dapat menjual produk pertanian mereka ke perusahaan, mereka mendapatkan pengetahuan baru dan teman baru dari daerah lain, dan sumber daya alam dapat diproses untuk meningkatkan kondisi perekonomian dan kualitas kehidupan mereka. 8\% responden tidak mengetahui dampak positifnya, sementara $5 \%$, menyebutkan mereka mendapatkan beasiswa dari perusahaan. Secara terperinci, Tabel 4 berikut ini menunjukkan dampak positif dari perusahaan.

Tabel 4

Dampak Positif Perusahaan yang Beroperasi di Provinsi Riau

\begin{tabular}{llc}
\hline No & Persepsi Responden & Persentase \\
\hline 1 & Pengembangan wilayah & $23 \%$ \\
2 & Kesempatan kerja & $43 \%$ \\
3 & Bantuan-bantuan sosial & $12 \%$ \\
4 & Beasiswa & $5 \%$ \\
5 & Lain-lain & $9 \%$ \\
6 & Tidak tahu & $8 \%$ \\
\hline
\end{tabular}


Menurut Inyang (2013), riset tentang bagaimana dampak dari CSR yang dilakukan oleh perusahaan besar terhadap masyarakat memang telah banyak dilakukan. Ternyata, tidak hanya perusahaan besar saja yang bisa memberikan dampak ke masyarakat, perusahaan kecil dan menengah juga memiliki dampak yang signifikan pada masyarakat. Menurut standar Uni Eropa, yang termasuk perusahaan kecil menengah adalah perusahaan dengan jumlah tenaga kerja kurang dari 250 orang. Definisi ini mungkin akan berbeda dengan definisi usaha kecil menengah di negara lain. Usaha ini mampu mendukung pertumbuhan ekonomi dan kehidupan di negara-negara berkembang karena biasanya cenderung padat karya, menciptakan kesempatan kerja sehingga mampu mengurangi pengangguran, mendorong pertumbuhan ekonomi, meningkatkan perkembangan sektor swasta, dan menyediakan kesempatakan untuk distribusi pendapatan yang lebih merata.

Tidak hanya bagi perusahaan besar, berdasarkan beberapa penelitian yang telah dilakukan membuktikan bahwa pengimplementasian CSR bagi perusahaan kecil menengah juga mampu untuk meningkatkan penjualan, membuat diferensiasi merek, meningkatkan imej merek, meningkatkan rekrutmen, moral, dan retensi karyawan, meningkatkan hubungan kerja dengan pemerintah, kemampuan untuk mencapai segmen pasar baru, dan sebagainya.

Di Indonesia, Usaha Kecil dan Menengah disingkat UKM adalah sebuah istilah yang mengacu ke jenis usaha kecil yang memiliki kekayaan bersih paling banyak Rp 200.000.000 tidak termasuk tanah dan bangunan tempat usaha. Dan usaha yang berdiri sendiri. Menurut Keputusan Presiden RI no. 99 tahun 1998 pengertian Usaha Kecil adalah: "Kegiatan ekonomi rakyat yang berskala kecil dengan bidang usaha yang secara mayoritas merupakan kegiatan usaha kecil dan perlu dilindungi untuk mencegah dari persaingan usaha yang tidak sehat." Di Indonesia, UKM adalah tulang punggung ekonomi Indonesia. Jumlah UKM hingga 2011 mencapai sekitar 52 juta. UKM di Indonesia sangat penting bagi ekonomi karena menyumbang $60 \%$ dari PDB dan menampung $97 \%$ tenaga kerja. Tetapi akses ke lembaga keuangan sangat terbatas baru $25 \%$ atau 13 juta pelaku UKM yang mendapat akses ke lembaga keuangan. Pemerintah Indonesia, membina UKM melalui Dinas Koperasi dan UKM, di masing-masing Provinsi atau Kabupaten/Kota (http://id.wikipedia. org/wiki/Usaha_Kecil_dan_Menengah).

Dari sisi manajemen pemasaran, praktek CSR oleh perusahaan dapat meningkatkan imej merek yang dihasilkan perusahaan. Hal ini berdasarkan hasil penelitian Khan dan Manwani (2013). Hasil penelitian mereka menyatakan karena kesempatan yang dirasakan untuk melakukan sesuatu yang baik dengan mendukung perusahaan yang merubah caranya beroperasi, konsumen lebih mungkin untuk mendukung perusahaan yang bertujuan melayani dan membantu menolong masyarakat dengan perilaku yang bertanggungjawab sosial. Kajian literatur dan penelitian menunjukkan bahwa peningkatan ekuitas merek, kinerja perusahaan yang lebih baik, dan pengembangan imej perusahaan, dapat dicapai melalui praktek 
CSR yang jujur dan adil dan dengan meningkatkan implemetasi kesejahteraan. CSR merupakan salah satu cara terbaik untuk menciptakan imej merek, yaitu dalam konteks lebih murah dibandingkan biaya promosi dan periklanan dalam jumlah yang sangat besar. CSR merupakan alat yang sangat penting untuk mengentaskan kemiskinan, mengatasi masalah pengangguran, pembebasan buta huruf, gangguan kesehatan, dan penurunan moral.

Selain dampak positif, terdapat beberapa dampak negatif dari perusahaan.
Persentase tertinggi adalah pencemaran udara dari perusahaan (19\%). Kemudian sampah (15\%) dan kerusakan lingkungan (14\%). Hampir sepertiga responden tidak tahu apakah perusahaan memiliki dampak negatif atau tidak. Dampak negatif lain yang dipersepsikan responden adalah jika perusahaan tidak stabil, maka perusahaan tersebut dapat ditutup kapan saja, kurangnya produk yang dihasilkan, nepotisme, kebisingan, dan sebagainya. Untuk lebih jelasnya mengenai dampak negatif yang dipersepsikan responden, dapat dilihat pada Tabel 5.

Tabel 5

Dampak Negatif Perusahaan yang Beroperasi di Propinsi Riau

\begin{tabular}{llc}
\hline No & Persepsi Responden & Persentase \\
\hline 1 & Polusi udara & $19 \%$ \\
2 & Sampah & $15 \%$ \\
3 & Kerusakan lingkungan & $14 \%$ \\
4 & Lingkungan yang tidak nyaman & $13 \%$ \\
5 & Lain-lain & $8 \%$ \\
6 & Tidak tahu & $31 \%$ \\
\hline
\end{tabular}

Polusi udara memiliki berbagai dampak negatif, antara lain penipisan lapisan Ozon, pemanasan global (Global Warming), penyakit yang menyerang pernapasan seperti jantung, paru-paru dan tenggorokan, terganggunya fungsi reproduksi, stres dan penurunan tingkat produktivitas, penurunan kesehatan dan penurunan kemampuan mental dan kecerdasan anak-anak. Pada umumnya, polusi udara di perkotaan semakin meningkat akibat praktik produksi, transportasi dan konsumsi yang tidak ramah lingkungan. Pembakaran bahan bakar fosil terus terjadi, meningkatkan emisi $\mathrm{CO}_{2}$ dan gas rumah kaca di udara, memicu pemanasan global dan perubahan iklim. Negara industri menyumbang 52\% emisi gas rumah kaca penyebab pemanasan global dan krisis iklim. Sementara negara berkembang termasuk Indonesia - menyumbang $48 \%$ sisanya. Dari $48 \%$ emisi gas rumah kaca pada periode 1850-2010, China menempati rangking pertama dengan kontribusi emisi gas rumah kaca sebesar $11,6 \%$. Indonesia menempati rangking ke-2 di bawah China sebagai negara berkembang penghasil emisi gas rumah kaca terbesar dengan kontribusi 4,8\%. Khusus Indonesia, sebanyak $60-70 \%$ emisi gas rumah kaca di Tanah Air dihasilkan dari deforestasi dan alih guna lahan yang dipicu oleh eksploitasi hasil 
tambang dan sumber daya alam. Untuk wilayah Riau, perambahan hutan terjadi sejak lama dan kalkulasi disepanjang tahun 2009-2012 menunjukkan hutan di wilayah itu makin sempit. Selain permasalahan deforestasi, kebakaran hutan yang menimbulkan kabut asap menjadi bencana tahunan di Indonesia, khususnya di Riau yang berdampak pada masalah transportasi, kegiatan ekonomi, lingkungan, kesehatan, serta hubungan regional. Menurut Wahana Lingkungan Hidup Indonesia (WALHI), kebakaran lahan dan hutan telah terjadi sejak tahun 1997 di Riau dengan modus dan motif yang selalu sama yaitu pembakaran lahan untuk pertanian.

Beberapa contoh klasik yang kerap menjadi bahan pembelajaran dalam CSR Industri Migas di antaranya adalah peristiwa kecelakaan tanker ExxonValdez pada 1989 dan mengakibatkan tumpahnya sekitar 10,8 juta barel minyak mentah di wilayah Prince William Sound, Alaska. Hingga saat ini ekosistem di seputar tumpahan minyak tersebut tidak pernah pulih seperti sedia kala (Frynas, 2009).

Sebenarnya, dampak negatif yang terjadi di lingkungan tidak hanya sematamata kontribusi dari perusahaan. Beberapa riset menyatakan bahwa aktivitas sehari-hari manusia juga turut mempengaruhi kelestarian lingkungan. Berdasarkan hasil studi Kementerian Lingkungan Hidup (KLH) tahun 2012 menunjukkan bahwa Indeks Perilaku Peduli Lingkungan (IPPL) masih berkisar pada angka 0,57 (dari angka mutlak 1). Hal ini mengindikasikan bahwa masyarakat kita belum berperilaku peduli lingkungan dalam menjalankan kehidupan sehari-hari. Perilaku konsumsi masyarakat dalam pemenuhan kebutuhannya, $49.3 \%$ berupa bahan makanan yang berasal dari luar daerahnya. Kondisi ini tentunya akan memberikan dampak bagi lingkungan seperti meningkatnya emisi karbon kegiatan pengangkutan bahan makanan tersebut dari daerah asal ketempat tujuan. Dari 6 indikator perilaku: konsumsi energi, membuang sampah, pemanfaatan air bersih, pemanfaatan bahan bakar, penyumbang emisi karbon dan perilaku hidup sehat, nilai terburuk adalah perilaku pemanfaatan bahan bakar yaitu level 0.28. (http://www.menlh.go.id)

Selanjutnya Tabel 6 berikut menampilkan data mengenai persepsi responden pada pertanyaan perusahaan apa yang menurut mereka paling bertanggungjawab.

Tabel 6

Perusahaan yang Dianggap Paling Bertanggungjawab Sosial

\begin{tabular}{llc}
\hline No & Persepsi Responden & Persentase \\
\hline $\mathbf{1}$ & PT. Chevron Pacific Indonesia & $18 \%$ \\
2 & PTPN V & $4 \%$ \\
3 & RAPP & $3 \%$ \\
4 & PT. Pertamina & $1 \%$ \\
5 & Lain-lain & $4 \%$ \\
6 & Tidak tahu & $70 \%$ \\
\hline
\end{tabular}


Sangat mengejutkan bahwa $70 \%$ responden tidak mengetahui perusahaan apa yang menurut mereka paling bertanggungjawab secara sosial. Persentase tertinggi jawaban responden adalah PT. CPI (18\%) dan diikuti oleh PTPN V (4\%), PT. RAPP (3\%), dan PT. Pertamina (1\%). Namun, fenomena ini tidak hanya terjadi di Indonesia. Sebuah penelitian di Amerika (2009) menyatakan bahwa tidak ada perusahaan yang dianggap paling bertanggungjawab sosial. Lebih jauh, persepsi konsumen terhadap CSR tidak berkorelasi dengan rangking CSR yang ada seperti CRO 100. CRO 100 adalah salah satu rangking yang dibuat dalam rangka membandingkan perusahaan-perusahaan besar dari beberapa aspek terkait dengan kegiatan perusahaan, seperti dampak lingkungan, perubahan iklim, hak-hak pekerja, hubungan perburuhan, kegiatan filantropi, keuangan, dan kebijakan pemerintah. Kinerja merek pada matrik persepsi konsumen tidak berkorelasi dengan kinera CSR aktual sebagaimana diukur oleh CRO 100.

Penelitian lain yang dilakukan oleh Carrigan dan Attala (2001) menampilkan hasil penelitian dari Dragon International's research yang melaporkan bahwa hanya $26 \%$ of responden dapat memberikan nama sebuah perusahaan, yang mereka persepsikan bertanggung jawab sosial. Hal ini berarti bahwa konsumem memiliki tingkat kesadaran yang rendah dan tidak memiliki cukup informasi mengenai kegiatan perusahaan dalam hal ini yang terkait dengan kegiatan tanggung jawab sosialnya.

Persepsi masyarakat Amerika ini agak mirip dengan masyarakat Riau. Barangkali beberapa perusahaan memang benar-benar melakukan kegiatan CSR, seperti tiga perusahaan yang potensial mendapatkan penghargaan dari Menteri koperasi dan UKM yaitu PT. Chevron Pacific Indonesia (CPI), PT. Riau Andalan Pulp and Paper (RAPP) dan Kelompok Sinar Mas. Tetapi $70 \%$ responden tidak mengetahui mereka sebagai perusahaan yang bertanggungjawab sosial. Kasus ini barangkali merupakan indikasi bahwa perusahaan yang sudah berinvestasi di kegiatan CSR perlu melakukan komunikasi ke masyarakat dengan lebih tepat agar masyarakat mengetahui komitmen mereka dalam menjalankan CSR ini.

Hal ini senada dengan hasil penelitian Du, Bhattacharya, dan Sen (2010) yang menemukan bahwa dengan melakukan tanggung jawab sosial perusahaan (CSR), perusahaan tidak hanya dapat menghasilkan sikap yang menguntungkan dari para stakeholders dan perilaku dukungan yang lebih baik (misalnya pembelian, mencari pekerjaan, investasi di perusahaan), tetapi juga, dalam jangka panjang, membangun citra perusahaan, memperkuat hubungan stakeholders dan perusahaan, dan meningkatkan perilaku advokasi stakeholders. Namun, rendahnya kesadaran stakeholders dan atribusi yang tidak menguntungkan terhadap kegiatan CSR perusahaan merupakan hambatan penting dalam upaya perusahaan untuk memaksimalkan keuntungan bisnis dari kegiatan CSR mereka. Hal ini menggarisbawahi kebutuhan bagi perusahaan untuk mengkomunikasikan CSR lebih efektif kepada para stakeholders.

Koran Harian Republika (2010) menyatakan bahwa implementasi CSR di Indonesia belum terkoordinasi dengan baik. Setiap perusahaan melakukan 
dengan cara mereka masing-masing dan kadangkala hal itu tidak menyelesaikan masalah yang ada di masyarakat. Program CSR sangat penting untuk menyelesaikan masalah kemiskinan yang ada di masyarakat. Itulah mengapa program CSR harus terkordinasi dengan baik untuk menyelesaikan masalah mendasar. Siregar (2007) menyatakan bahwa banyak perusahaan tidak mau mengimplementasikan CSR karena mereka menghitungnya sebagai biaya. Implementasi CSR masih menghadapi beberapa hambatan, yaitu programnya masih belum disosialisasikan. Hambatan lainnya adalah perbedaan sudut pandang antara departemen Hukum dan HAM dengan Departemen Perindustrian. Selain itu masih terdapat hambatan lain berupa tidak ada peraturan yang jelas untuk pengimplementasian CSR. Namun walau bagaimanapun, program CSR dapat meningkatkan semangat kebersamaan diantara komunitas masyarakat yang berbeda.

Menurut berita di Koran Riau Sidik, pada bulan Agustus 2010, mahasiswa Universitas Lancang Kuning menuduh PT. CPI menciptakan limbah berbahaya yang merusak lingkungan. Pantauan Sidik dilapangan pada tanggal 16 Juli 2010, di daerah PT. Chevron Pasific Indonesia Minas disekitar lokasi 6D, kurang lebih 2 hektar di kebun kelapa sawit warga, ditemukan beberapa titik gumpalan minyak mentah (limbah) setebal $30-40 \mathrm{~cm}$, diduga sengaja dibuang oleh PT. CPI, hal tersebut dapat terlihat dari kawasan itu cukup jauh dari lintasan pipa minyak PT.CPI. Selanjutnya dampak dari limbah tersebut dilokasi ditemukan sejumlah tanaman terlihat kering (mati), hal ini membuktikan bahwa limbah dimaksud adalah beracun dan merupakan Limbah B3, artinya belum melewati proses land application. Setelah diberitahukan ke pihak CPI, dan pihak CPI mengaku sedang turun kelapangan (Koran Riau Sidik, 2010).

Pencemaran tanah adalah keadaan dimana bahan kimia buatan manusia masuk dan mengubah lingkungan tanah alami. Pencemaran ini biasanya terjadi karena: kebocoran limbah cair atau bahan kimia industri atau fasilitas komersial; penggunaan pestisida; masuknya air permukaan tanah tercemar ke dalam lapisan sub-permukaan; kecelakaan kendaraaan pengangkut minyak, zat kimia, atau limbah; air limbah dari tempat penimbunan sampah serta limbah industri yang langsung dibuang ke tanah secara tidak memenuhi syarat (illegal dumping).

Terkait dengan pencemaran di tanah, data dari penelitian ini menunjukkan bahwa 9\% responden sangat setuju bahwa limbah perusahaan berbahaya bagi lingkungan, sementara $31 \%$ menjawab setuju, dan sekitar $6 \%$ responden memberikan jawaban netral. Hal yang menarik adalah secara kolektif persentase responden yang berpartisipasi dalam penelitian ini yang menjawab tidak setuju dan sangat tidak setuju lebih besar yaitu masing-masing 27\%. Sehingga terlihat seperti terdapat sedikit ketidakkonsistenan sikap. Namun hal ini dapat disebabkan tingkat kesadaran lingkungan yang mungkin belum tinggi ataupun tidak tereksposnya berita terkait di media. Media penyampaian begitu beragam, dan tidak semua merupakan media yang paling diminati mahasiswa saat ini. Adapun jawaban responden selengkapnya dapat dilihat pada Tabel 7 berikut ini. 
Tabel 7

Persepsi Responden Mengenai Limbah Perusahaan Berbahaya bagi Lingkungan

\begin{tabular}{llc}
\hline No & Persepsi Responden & Persentase \\
\hline 1 & Sangat setuju & $9 \%$ \\
2 & Setuju & $31 \%$ \\
3 & Netral & $6 \%$ \\
4 & Tidak setuju & $27 \%$ \\
5 & Sangat tidak setuju & $27 \%$ \\
\hline
\end{tabular}

Selanjutnya, untuk pertanyaan apakah kehadiran pendatang menganggu kehidupan sosial di masyarakat terlihat bahwa mayoritas responden tidak setuju akan hal itu. Adapun jawaban selengkapnya dapat dilihat pada Tabel 8.

Tabel 8

Jawaban Responden Mengenai Kehadiran Pendatang Mengganggu Kehidupan Sosial

\begin{tabular}{llc}
\hline No & Persepsi Responden & Persentase \\
\hline 1 & Sangat setuju & $1 \%$ \\
2 & Setuju & $3 \%$ \\
3 & Netral & $28 \%$ \\
4 & Tidak setuju & $62 \%$ \\
5 & Sangat tidak setuju & $6 \%$ \\
\hline
\end{tabular}

Dari sisi lowongan pekerjaan, responden juga tidak merasa tersaingi dengan adanya pendatang yang kadangkala bagi sebagian orang hal ini menambah persaingan dalam mengisi lowongan pekarjaan yang ada. Apalagi adakalanya para pendatang memang memiliki keahlian yang lebih tinggi sehingga mampu menduduki posisi-posisi yang lebih tinggi pula.

Menurut analisis secara teori pasar tenaga kerja, pengaruh adanya pendatang yang mencari kerja aakan membuat perubahan dari sisi ketersediaan tenaga kerja dan terjadinya perubahan keseimbangan pasar tenaga kerja. Khususnya perbedaan akan terlihat dari tenaga kerja yang memiliki keahlian dan yang tidak memiliki keahlian. Masuknya tenaga kerja dari pendatang akan mengubah komposisi keahlian angkatan kerja jika komposisi tenaga kerja pendatang tidak seperti penduduk lokal. Perubahan komposisi keahlian ini akan mengarahkan pada ketidakseimbangan antara penawaran dan permintaan meminimumkan biaya untuk jenis tenaga kerja yang berbeda pada tingkat output dan upah yang sama. Dalam jangka pendek hal ini menyebabkan perubahan gaji dan jumlah orang yang bekerja sementara dalam jangka panjang dapat menyebabkan perubahan output yang dihasilkan (Dustmann, Fabbri, dan Preston). Lebih jauh, Borjas (2003) menemukan bahwa tenaga kerja 
pendatang dapat menurunkan gaji dimana setiap peningkatan $10 \%$ penawaran tenaga kerja akan menurunkan gaji antara $3-4 \%$.

Kenyataannya, pada penelitian ini sekitar 59\% responden menjawab tidak setuju dan sangat tidak setuju bahwa pendatang memiliki kesempatan kerja dan peluang yang lebih besar. Ringkasan jawaban responden mengenai pendatang berpeluang lebih besar dapat dilihat pada Tabel 9.

Tabel 9

Jawaban Responden Mengenai Pendatang Berpeluang Lebih Besar

\begin{tabular}{llc}
\hline No & Persepsi Responden & Persentase \\
\hline 1 & Sangat setuju & $3 \%$ \\
2 & Setuju & $36 \%$ \\
3 & Netral & $2 \%$ \\
4 & Tidak setuju & $50 \%$ \\
5 & Sangat tidak setuju & $9 \%$ \\
\hline
\end{tabular}

Menurut pasal $18 \quad$ Perda Penempatan Tenaga Kerja Lokal Kota Pekanbaru tahun 2002, Pengusaha sebagaimana dimaksud pada pasal 17 Peraturan daerah ini wajib mengupayakan bertahap dalam waktu 5 tahun pertama pengisian lowongan pekerjaan di perusahaannya diisi oleh tenaga kerja lokal minimal $50 \%$ dan pada 5 tahun berikutnya minimal menjadi $75 \%$ dari jumlah tenaga kerja yang bekerja di perusahaannya. Selanjutnya, pasal 19 ayat 1 menyatakan pengusaha diharuskan untuk membuat perencanaan pengisian atau perencanaan penggatian posisi jabatan middle management $\mathrm{di}$ perusahaannya dengan tenaga kerja lokal yang memenuhi kriteria untuk jabatan tersebut minimal $30 \%$ dari jumlah posisi jabatan yang ada di dalam batas waktu 10 tahun. Pada ayat 2 dinyatakan bahwa khusus jabatan menajer personalia di perusahaan wajib diisi oleh tenaga kerja lokal.

Perda ini dapat menjadi panduan untuk melindungi tenaga kerja lokal dari persaingan dengan tenaga kerja pendatang. Bahkan lebih jauh pasal 21 menyatakan untuk menghindari timbulnya kecemburuan sosial masyarakat yang berdomisili di sekitar lokasi perusahaan, pengusaha wajib untuk dapat menerima tenaga kerja tempatan untuk pekerjaan yang tidak memerlukan keterampilan teknis atau khusus, pekerjaan tersebut antara lain tukang kebun, cleaning service, penjaga malam, dan sebagainya.

Pada prakteknya, Dinas Tenaga Kerja (Disnaker) Pekanbaru memastikan tiga ritel yang beroperasi di Pekanbaru tidak menyalahi Perda tenaga kerja. Hal itu ditegaskan Kadisnaker Pekanbaru Pria Budi, Senin, (28/4/2013).

Menurutnya Disnaker telah melakukan pengawasan dan pendataan terkait penyerapan tenaga kerja lokal terhadap tiga ritel yang beroperasi di Pekanbaru seperti Indomart, Alfamart dan Giant. Pendataan berdasarkan berkas hasilnya ketiga ritel tersebut sudah mentaati perda tentang mempekerjakan tenaga lokal 50 persen. 
Selain terjadi penyerapan tenaga kerja, kehadiran perusahaan memiliki dampak positif pula berupa perkembangan daerah yang ada di-sekitarnya. Pada penelitian ini, dampak positif yang dipersepsikan oleh responden adalah perusahaan menciptakan kesempatan bisnis di daerah mereka. Misalnya dengan banyaknya pendatang untuk bekerja di perusahaan, mereka membutuhkan penyedia kebutuhan sehari-hari seperti makanan, tempat tinggal, jasa binatu, jasa transportasi, dan sebagainya. Sekitar 79\% responden setuju dan sangat setuju bahwa perusahaan menciptakan kesempatan bisnis baru bagi masyarakat.

Tabel 10

Jawaban Responden Mengenai Kesempatan Bisnis yang Muncul

\begin{tabular}{llc}
\hline No & Persepsi Responden & Persentase \\
\hline 1 & Sangat setuju & $48 \%$ \\
2 & Setuju & $31 \%$ \\
3 & Netral & $5 \%$ \\
4 & Tidak setuju & $14 \%$ \\
5 & Sangat tidak setuju & $2 \%$ \\
\hline
\end{tabular}

\section{Perusahaan yang Dipersepsikan Bertanggungjawab Sosial}

Untuk menjadi perusahaan yang dipersepsikan memiliki tanggung jawab sosial, ada beberapa aspek yang perlu diperhatikan. Penelitian ini mencoba memandangnya dari beberapa sisi, antara lain bagaimana perusahaan memperlakukan karyawannya, lingkungan, masyarakat, dan kedermawanan yang diharapan. dari sudut pandang perlakuan terhadap karyawan, diberikan empat alternatif pilihan jawaban bagi responden. Lebih dari separuh responden memilih lebih dari satu kegiatan yang harus dilakukan untuk menjadi perusahaan yang bertanggungjawab sosial. Persentase tertinggi menyatakan perusahaan harus memperlakukan karyawannya dengan baik, kemudian diikuti dengan kesempatan untuk mendapatkan promosi atau kenaikan jabatan yang sama dengan tenaga kerja lain. Selanjutnya responden juga menjawab adanya persaingan yang adil dan kompensasi yang memadai.

Peran CSR terhadap karyawan menjadi semakin penting saat ini dalam dunia bisnis. Salah satu alasanya adalah perusahaan yang sukses harus mampu menarik dan mempertahankan angkatan kerja terbaik. Dengan menciptakan lingkungan yang baik dan mengembangkan strategi pemasaran internal, perusahaan dapat mendorong produktivitas dan kepuasan antar karyawan. Jika karyawan puas mereka akan merekomendasikan ke keluarga dan teman sebagai karyawan yang baik. (Bhattacharya et al., 2008 dalam Tyagi dan Gupta, 2012). Karyawan yang puas biasanya akan memberikan kinerja terbaik bagi organisasi. Apabila tujuan individu dan tujuan organisasi dapat diselaraskan, organisasi akan terhindar dari permasalahan tingginya perputaran tenaga kerja yang dapat menurunkan produktivitas perusahaan. 
Tabel 11

Tanggung Jawab Sosial Perusahaan pada Karyawan

\begin{tabular}{lll}
\hline No & Kegiatan Perusahaan & Persentase \\
\hline 1 & Karyawan diperlakukan dengan baik & $77 \%$ \\
2 & Karyawan memiliki kesempatan yang sama untuk & $66 \%$ \\
3 & dipromosikan. & $59 \%$ \\
4 & Persaingan yang adil & $59 \%$ \\
\hline
\end{tabular}

Dalam penelitian ini, terdapat pertanyaan terbuka yang membebaskan responden mengisi sesuai pendapatnya. Berdasarkan jawaban bebas responden berharap perusahaan menjalin hubungan baik dengan masyarakat, memberikan asuransi kepada pegawai, tidak ada diskriminasi berdasarkan ras, saling menghormati, memberikan pelatihan, dan lain-lain. Selanjutnya Tabel 12 menggambarkan persentase persepsi responden tentang bagaimana perusahaan yang bertanggungjawab sosial memperlakukan lingkungannya.

Tabel 12

Tanggung Jawab Sosial Perusahaan pada Lingkungan

\begin{tabular}{lll}
\hline No & Kegiatan Perusahaan & Percentage \\
\hline $\mathbf{1}$ & Beroperasi dengan ramah lingkungan & $81 \%$ \\
2 & Produk bisa di daur ulang & $74 \%$ \\
$\mathbf{3}$ & Efisien memanfaatkan energi & $74 \%$ \\
\hline
\end{tabular}

Sekitar $81 \%$ memilih beroperasi dengan ramah lingkungan, dan $74 \%$ menyatakan produk yang dihasilkan harus bisa di daur ulang dan efisien dalam memanfaatkan energi. Responden juga menyatakan sebaiknya perusahaan membangun pabrik jauh dari perumahan masyarakat, memelihara fasilitas publik, memperbaiki jalan yang rusak, tidak sembarangan membuang limbah, membayar kompensasi jika aktivitas perusahaan menyebabkan polusi pada lingkungan, tidak memberikan dampak buruk pada masyarakat, sampah bisa di daur ulang, dan sebagainya. Perusahaan hendaknya juga memiliki tanggung jawab sosial pada masyarakat. Jawaban responden untuk hal ini dipaparkan pada Tabel 13.

\section{Tabel 13}

Tanggung Jawab Sosial Perusahaan terhadap Masyarakat

\begin{tabular}{lll}
\hline No & Kegiatan Perusahaan & Percentage \\
\hline 1 & Peduli pada masyarakat & $83 \%$ \\
2 & Memberi bantuan pada masyarakat & $70 \%$ \\
\hline
\end{tabular}


Mayoritas responden menyatakan bahwa perusahaan harus peduli pada masyarakat $(83 \%)$ dan memberi bantuan pada masyarakat (70\%). Selain itu, diharapkan perusahaan melakukan aktivitas sosial, menyediakan lapangan kerja bagi masyarakat di sekitar, memperbaiki infrastruktur, menjadikan kesejahteraan masyarakat sebagai prioritas utama, membantu di bidang pendidikan, beasiswa untuk masyarakat miskin disekitar perusahaan, dan sebagainya.

\section{KESIMPULAN}

CSR adalah suatu konsep bahwa organisasi memiliki suatu tanggung jawab terhadap semua pihak yang akan dipengaruhi oleh segala aspek operasional perusahaan. Terdapat dampak positif dan negatif yang dapat timbul sebagai konsekuensi berdirinya suatu perusahaan. Mengimplementasikan program CSR yang tepat, dapat meminimalisir atau menjadi kompensasi bagi dampak negatif yang muncul. Pengimplementasian program CSR seyogyanya berangkat dari kebutuhan masyarakat agar apa yang sudah susah payah dilakukan perusahaan terasa lebih bermanfaat bagi masyarakat. Penelitian ini menggambarkan bagaimana harapan masyarakat pada programprogram CSR yang sebaiknya dijalankan perusahaan oleh perusahaan di Propinsi Riau. Mengingat masih adanya ketidakpuasan masyarakat atas pelaksanaan program CSR, sebaiknya perusahaan mengkaji kembali mengenai jenis-jenis program CSR yang sesuai dengan kebutuhan dan harapan. Selain itu, pemanfaatan media yang tepat untuk mengkomunikasikan program CSR yang telah dan akan dilakukan perlu mendapat perhatian khusus, agar apa yang dilakukan mendapat apresiasi dan diketahui masyarakat, terutama yang terpengaruh secara langsung dengan aktivitas perusahaan.

\section{DAFTAR PUSTAKA}

Amine, M., E., Chakor, A., dan Alaoui, A., M. 2013. Corporate Ethical and Social Responsibility and Relationship Marketing: a Content analysis of the Websites of Moroccan Commercial Banks, Internationa Journal of Business and Management, Vol. 8 No.3, 71-102).

Anonym, 2007. Is the Green Consumer Trend Over? (Online), (http://www.environmentalleader. com, diakses tanggal 15 April 2013)

Anonym 2, Barneys Sells Green For The Holidays, (Online), (http://www.environmentalleader. com, diakses tanggal 15 April 2013)

Auppele, K. E., Carroll, A. B., \& Hatfield, J. D. (1985). An empirical investigation of the relationship between corporate social responsibility and profitability. Academy of Management Journal, 28, 446463.

Borjas, G.J. 2003. The Labor Demand Curve is Downward Sloping: Reexamining the Impact of 
Immigration on the Labor Market, The Quarterly Journal of Economics .118 (4): 1335-1374.

Bronn, P. S., \& Vrioni, A. B. (2001). Corporate Social Responsibility and Cause-related Marketing: An Overview. International Journal of Advertising, 20(2), 207-222.

CSR Asia, CSR in Asia: Who is Getting it Done?The Role of CSR Professional in Asia, (Online), (http://www.csrasia.com/report/report_csr_in_asia , diakses tanggal 12 April 2013)

Dawkins, J. \& Lewis, S. 2003. CSR in Stakeholders Expectation: and Their Implication for Company Strategy, Journal of Business Ethic, 44, 185-193.

Dean, D. H. 2003. Consumer Perception of Corporate Donations: Effect of Company Reputation for Social Responsibility and Type of Donation, Journal of Advertising, Vol. 32 No.4, 94-102.

Du, S., Bhattacharya, C.B., \& Sen, S. 2010. Maximizing Business Returns to Corporate Social Responsibility (CSR): The Role of CSR Communication, International Journal of Management Reviews, Volume 12, Issue 1, 8-19.

Du, S., Swaen, V., Lindgreen, A. Dan Sen, S. 2013. The Roles of Leadership Styles in Corporate Social Responsibility, $J$ Bus Ethics, Vol. 114, 155-169
Dustmann, C., Fabbri, F., \& Preston, I. The Impact of Immigration on the UK Labor Market, Discussion Paper Series, CDP No.01/5.

Frynas, J., G. 2009. Beyond Corporate Social Responsibility: Oil Mutinationals and Social Challenges, Cambridge University Press.

Giannarakis, G., dan Sariannidis, N. 2012. The Role of Corporate Social Responsibility in an Unstable Environment: An Examination of Trends 20082010, International Journal of Management, Vol. 29 No. 4, 579589.

Haluan Riau, 18 Maret 2011, Pengelolaan limbah Belum maksimal , (online), (http://www.riaumandiri.net, diakses tanggal 13 April 2013).

Hochgatterer, C. Does CSR increase firms' profits? Evidence from DJSI firms, (Online), (http://www.wu.ac.at, diakses tanggal 13 April 2013)

http://www.menlh.go.id

http://www.essay-911.com/samples/ effect.htm

http://andukot.wordpress.com/2010/08/03 /pt-chevron-tidak-ada-manfaatbagi-masyarakat/

http://bismar.wordpress.com/2009/12/23/t anggungjawab-sosial-perusahaan/ 
http://id.wikipedia.org/wiki/ Kepemimpinan)

http://id.wikipedia.org/wiki/Usaha_Kecil _dan_Menengah.

Inyang, B., J. 2013. Defining the Role Engagement of Small and Medium-Sized Enterprises (SMSs) in Corporate Social Responsibility, International Business Research, Vo. 6 No.5, 123-132.

Khan, A. A., dan Manwani, D. T. 2013. Sustainability \& Corporate Brand Equity through Corporate Social Responsibility Initiatives, Asia Pacific Journal of Management \& Entrepreneurship Research (APJMER), Vol. 2 Issue 2, 267279.

Majumdar, S., dan Saini, G. K. 2013. Perception of Corporate Social Responsibility: a Study of Social Segments in the Indian State of Goa, South Asian Journal of Management, Vol. 20 No.1, 139150.

McWilliams, A. \& Siegel, D. 2000. Corporate Social Responsibility and Financial Performance: Ccorrelation or Mmisspecification? Strategic Management Journal, Volume 21, Issue 5, 603-609.

Peraturan Pemerintah Republik Indonesia Nomor 47 Tahun 2012 Tentang Tanggung jawab Sosial dan Lingkungan Perseroan Terbatas.
Peraturan Daerah Kota Pekanbaru Nomor 4 tahun 2002.

Raman, M., Lim, W., dan Nair, S. 2012. The Impact of Social Responsibility on Consumer Loyalty, Kajian Malaysia, Vo. 30 No.2, 71-93

Riau Terkini, 12 Agustus 2010, BUMN Diminta Serius Kucurkan CSR Perusahaan, (Online), (http://www.riauterkini.com, diakses 12 April 2013)

Siregar, C.N., 2007. Analisis Sosiologis Terhadap implementasi Corporate Social Responsibility pada Masyarakat Indonesia, Jurnal Sosioteknologi, Edisi 12, Tahun 6, Desember, 285-288

Ribeiro, S. 2010. Green Consumer Attitudes and the Emerging Buying Power of Eco-Moms, http://greeneconomypost.com/sb1 0-consumer-attitudes-eco-moms10535.htm

Sriramesh, K., Ng, C.W., Ting, S.T., and Wanyin, L. 2007. Corporate Social Responsibility and Public Relations, Perception and Practices in Singapore, Paper Submitted to the $14^{\text {th }}$ International Public Relations Symposium, Bled, Slovenia, July 3-5 2007.

Sule, E.T., Saefullah, K., 2005, Pengantar Manajemen, Edisi Pertama, Prenada Media, Jakarta

Tanudjaja, B., B. 2006. Perkembangan Corporate Social Responsibility di 
Indonesia, Nirmana, Vol. 8 No. 2, 92-98.

Tyagi, A., dan Gupta, N. 2012. The Impact of CSR (Corporate Social Responsibility) and Sustainable Business Development on Employee, International Journal of Management Research and Review, Vol. 2 Issue 11, 20092014.

M
Vermillion, 2010. Go Green: Five green consumer trends for 2011, (Online), (http://www.granitefallsnews.com, diakses tanggal 12 April 2013)

Vivanews, Bakri Sumatera Raih Penghargaan CSR Terbaik, (Online), (http://bisnis. vivanews.com, diakses tanggal 15 April 2013) 